\title{
LEIODINAE AND CATOPINAE (COLEOPTERA; LEIODIDAE) FROM JAMAICA AND PUERTO RICO*
}

\author{
By Stewart B. Peck \\ Department of Biology, \\ Carleton University, \\ Ottawa, Ontario, Canada
}

The Leiodidae of the West Indies are poorly known. In the subfamily Catopinae, only six species in two genera are reported; one Dissochaetus from Puerto Rico and one each from St. Vincent and Grenada; and three species of Proptomaphaginus, one from Puerto Rico and two from Cuba (Peck 1970). In the subfamily Leiodinae only three species are known: Cyrtusa conicitarsus Champion 1925, from St. Vincent and Grenada; Aglyptinus guadelupensis Portevin 1942, from Guadeloupe; and $A$. kaszabi Hlisnikovsky 1964, from Guadeloupe. Although Wolcott (1936) mentions an Aglyptinus from Puerto Rico, it was intercepted in Inga laurina pods of unmentioned origin by Agriculture inspectors and may not be the native species.

This paper reports on collections I made during field studies on the evolution and distribution of West Indian Leiodidae in Puerto Rico in 1966-1967 and in March-April 1968 in Jamaica. Data on collecting sites and methods used in Puerto Rico are in my 1970 paper. Jamaican collections were made by extracting the fauna with Berlese funnels from a total of 220 pounds (I99 liters) of sifted forest litter taken at 4 localities; by Io carrion-baited pitfall traps set for a total of 90 effective trapping days in the vicinity of Hardwar Gap in the Blue Mountains; and by collecting in seven caves. Puerto Rican and Jamaican material, collected by M. W. Sanderson and H. B. Mills of the Illinois Natural History Survey, is included, and is indicated by (INHS).

In this work, 126 specimens of a new Dissochaetus, 94 specimens of two new Aglyptinus, and 7 specimens of a new Creagrophorus were found in Jamaica, and 8 specimens of a new Aglyptinus in Puerto Rico. Paratypes have been placed in the collections of the Institute of Jamaica, Kingston; the Canadian National Collection, Canada Department of Agriculture, Ottawa; and the Illinois Nat-

*Manuscript received by the editor April 24, 1972. 
ural History Survey, Urbana. Other specimens have been retained in my collection.

\section{Subfamily Catopinae \\ Dissochaetus jamaicensis $\mathrm{n}$. $\mathrm{sp}$.}

Holotype, male (in Museum Comparative Zoology, Harvard, MCZ type \#32005). Type locality and data. Jamaica; St. Andrew-Portland Parishes, Hardwar Gap, 4000' elev., 31.iii-9.iv. 1968, S. Peck, A. Fiske leg., carrion trap. Paratypes, Io4 with same data.

Description. 2.3-2.8 $\mathrm{mm}$ long. I.2-1.5 $\mathrm{mm}$ wide. Winged. Color dark brown, lighter on antennal base, legs, and anterior center of elytra. Eyes large. Antennae normal, reaching first $\mathrm{I} / 5$ of elytra when laid back. Pronotum coarsely granulate; transverse, widest I/3 from base, I.5 times as wide as long; posterior angles obtuse. Elytra regularly rounded. Aedeagus (fig. I) elongate, drawn out at apex, shorter than parameres, no lateral hairs. Parameres thin, slightly enlarged and flattened at ends which curve toward each other, bearing 2 terminal setae. Internal sac armed, ligules absent. Genital segment (fig. 2) complete, longer than broad, sternite lobes thin and curved; pleurite lobes thin, with a few long setae.

Diagnosis and relationship. The species can easily be distinguished from all others by the characters of the aedeagus and the genital segment. The species belongs to the spinipes group of Jeannel (I9.36) because of its major metatarsal spur which is longer than the first metatarsomere, and of the characters of the aedeagus. This group contains the other known West Indian species of the genus. However, since the group is distributed through all the lands bordering the Caribbean Sea and the Gulf of Mexico, and the Dissochaetus fauna of most of this land is inadequately known, little about relationships or time or direction of migration can be said.

Collections and habitat data. Most of the specimens came from carrion-baited pitfall traps set in the cloud forest of Hardwar Gap. This is a moist to wet forest at $4000^{\prime}$ elevation, set aside as a forest reserve by the Jamaican Forest Service. Big trees are present on level ground, but much of the forest has a somewhat reduced stature. Epiphytes and tree ferns are abundant. The litter appeared rich but was not sampled with Berlese funnels. The following traps were set in various parts of this forest along a new road that was under construction, leading down to the north shore. T 309, along 
gully in dense ginger (Zingiberaceae) undergrowth, Io males, I2 females. T $3 \mathrm{IO}$, on edge of forested area in cluster of tree ferns and ginger, 4 males, IO females. $\mathrm{T} 3 \mathrm{I}$ I and $\mathrm{T} 3 \mathrm{I} 2$, hillside forest near stream, 2 males, $\mathrm{I} 2$ females; 3 males, 30 females. $T$ T 313 in midst of tree ferns with heavy undergrowth, some logging present, soil $6 \mathrm{I}^{\circ} \mathrm{F}$, I male, 6 females. T $3 \mathrm{I} 4$, dense forest, 3 males, il females.

The species was taken at three other sites: Trap 305 and 306, St. Andrews Parish, New Castle, 3000' elev., a cool moist forested ravine between milepost 16 and 17,6 males, 9 females. Trap 307 and 308, St. Andrews Parish, Greenwich, near New Castle, 3700' elev., a forest on a steep dryish talus slope, soil $63^{\circ} \mathrm{F}$, I male, 5 females. Berlese I19, St. Ann Parish, $3 \mathrm{mi} \mathrm{N}$ Ewarton, 6.iv.68, Peck \& Fiske, 2000' elev., 23 lbs (22 liters) sifted moist forest leaf litter and soil under human dung, I male.

In these collections, females (95) were three times as abundant as males (3I). It may be that they are more attracted by the bait since it may be a potential oviposition site. This is a better representation of males than in Dissochaetus portoricensis Hatch where I5 males and 2I5 females were collected (Peck 1970).

It is interesting to note in conclusion that Jamaica is known to have only this species of Catopinae, while each of the other two investigated Greater Antillean Islands (Cuba and Puerto Rico) have two species apiece.

\section{Subfamily Leiodinae Genus Aglyptinus Cockerell}

Diagnosis. Body hemispherical; not perfectly contractile; darkly colored; smooth, shining, lightly punctured. Size small, about r.5$2.5 \mathrm{~mm}$. Head flattened, antennal grooves distinct. Antennae slender; II segmented; 5 segmented club beginning with enlarged segment seven, segment eight smaller than seven and nine. Mesosternum with keel. Protarsi 3 segmented in females, 4 segmented in males; mesoand metarsi 3 segmented in both sexes.

The genus has I7 previously named species distributed from southern Canada to Paraguay and southern Brasil. Hlisnikovsky (1964) provides a thorough description of the genus, and a key to the species. I have found the named and new species difficult to distinguish by external features. Thus, my following descriptions emphasize the aedeagus which I believe to be the most useful character complex in the genus for species discrimination. 


\section{Aglyptinus dimorphicus n. sp.}

Holotype, male (in MCZ, type \#32002). Locality and data. Jamaica; Trelawney Parish, Windsor Great Cave (at Windsor, Io mi S Falmouth), 5.iv.68, S. Peck \& A. Fiske. Paratypes, 34 with same data.

Description. Length I.3-I.5 mm. Color rufotestaceous to piceous. Epipleuron often light in dark specimens. Eyes normal. Head, prothorax, and elytra with fine and scattered punctures, and hairs. Wings dimorphic; of normal length and apparently functional, or reduced to $3 / 4$ the length of the elytra and functionless. Aedeagus (fig. 3) long, thin, curved, sinusoidal at tip; in dorsal view (fig. 4), tip thin and pointed. Parameres thin, straight, about $2 / 5$ length of aedeagus.

Diagnosis. The wing dimorphism and characters of the aedeagus separate the species from others.

Variation. The aedeagus in some specimens is sometimes slightly broader in the middle and not quite so curved as illustrated in the lateral view. Wing dimorphism data are below.

Collections and habitat data. The type series contains 14 males and 2 I females, all with short wings, taken concentrated in a few areas of moist guano of insectivorous bats. Other specimens, all from Jamaica, are as follows: Clarendon Parish: Colonel's Ridge, I 4.v.I950, H. B. Mills, I short wing female (INHS). Manchester Parish: Mandeville, I4.iv.1959, M. W. Sanderson, I long wing female (INHS). Near Round Hill, I6.vi.1950, H. B. Mills (INHS). Portland Parish: Hardwar Gap, 9.v.I95o, H. B. Mills, I short wing male; I short wing female (INHS). St. Andrew Parish: Hermitage Dam, I750 ft. elev., Io.v.1950, H. B. Mills, one short wing male, one long wing and one short wing female (INHS). St. Ann Parish: $2.5 \mathrm{mi} \mathrm{S}$ Moneague, $2250 \mathrm{ft}$. elev. (Mt. Diablo), Ber II7 (forest litter, 6o pounds, 56 liters), 2 males, 8 females, all long winged. Ber i 8 , same data as Ber II 7 , but rotted logs (88 pounds, 8I liters) in forest, I male, I female, both with short wings. $3 \mathrm{mi} \mathrm{N}$ Ewarton, 6.iv.68, Peck \& Fiske, 2000' elev., Ber i I9 (leaf litter under human dung, 23 pounds, 22 liters), 2 females with long wings and I with short, 2 males with short wings. Mt. Diablo, I3.vi.r950, H. B. Mills, I female and 2 male short wing (INHS). Brownstown, I 4.v.I950, H. B. Mills, I long wing male (INHS). St. Catherine Parish: St. Claire Cave ( I I $/ 2 \mathrm{mi} \mathrm{SW} \mathrm{Ewarton),} \mathrm{7.iv.68,} \mathrm{Peck} \mathrm{\&} \mathrm{Fiske,} 2$ short winged females. I I $/ 2 \mathrm{mi}$ SW Ewarton, 7.iv.68, Peck \& Fiske, IOoo' 
elev., Ber I20 (dryish leaf litter at tree base, 2 I pounds, 40 liters), I male and female with long wings, 3 males and 3 females with short wings. St. Elizabeth Parish: Southfield, I6.v.1950, H. B. Mills, I long wing female (INHS). St. Thomas Parish: Corn Puss Gap, Ir.v.1950, H. B. Mills, I male and I female short wing, I long wing male. Trelawney Parish: Drip Cave ( I I $/ 2$ mi SSE Stewart Town), 2.vi.68, Peck \& Fiske, I3 males, I6 fenales, all with short wings, from moist guano.

The data show the species to be present in caves and forest litter at low and middle elevations. The cave populations are all short winged. Forest litter populations contain long and short winged males and females. The sample is inadequate to compute the relative frequency of short wings in the litter populations and any possible relationship to sex. Wing dimorphism has not been noted for other members of the genus. The species is syntopic with the following, for both species were collected in Berlese sample II8, and at Corn Puss Gap.

\section{Aglyptinus jamaicensis n. sp.}

Holotype, male (in MCZ, type \# 32003). Locality and data. Jamaica; St. Ann Parish, 2.5 mi S Moneague, 3.vi.rg68, S. Peck and A. Fiske, 2250' elev., Ber I I 8 (rotted logs in forest, 88 pounds, 8I liters). Paratypes, 5 males and 9 females with same data; and 2 males, 2 females, St. Thomas Parish, Corn Puss Gap, I I.v.I95o, H. B. Mills (INHS).

Description. Length I.I-I.5 mm. Color piceous. Eyes and wings normal. Head, prothorax, and elytra with fine and scattered hairs and punctures. Aedeagus (fig. 5) broad at base, gradually tapering and curving; in dorsal view (fig. 6) tip broad and narrowing rapidly to apex. Parameres short, thin, bent at tips.

Diagnosis. The characters of the aedegus separate the species from all others.

Variation. In some specimens the aedeagus is narrower at the tip and narrower in the center in the lateral view than illustrated. There is, nevertheless, a clear gap in shape between this and the preceding species.

Habits. This and the preceding species are syntopic. This species was not found in caves or lowland forest litter. It may be more common in the higher elevation forests, where I did not extensively collect. 


\section{Aglyptinus puertoricensis n. sp.}

Holotype, male (in MCZ, type \#32004). Locality and data. Puerto Rico; Toro Negro Forest, Cerro Dona Juana, IOoo m elev., 28.xii.1966-4.i.1967, S. Peck, yeast bait trap. Paratypes, I male and 2 females with above data; I male and 2 females, Puerto Rico, Luquillo Experimental Forest, $300 \mathrm{~m}$ elev., 26.xii.I966-I.i.I967, S. Peck, yeast trap; I male, Puerto Rico, Maricao State Forest, I.vii.1958, M. W. Sanderson, beating and sweeping (INHS).

Description. I.4-I.7 mm. Color piceous. Eyes and wings normal. Head, prothorax, and elytra with fine and scattered punctures and hairs. Aedeagus (fig. 7) broadest at base, narrowing and curving to middle, from middle to tip straight, gradually narrowing to tip ; in dorsal view (fig. 8), tip pointed, narrowing towards middle. Parameres straight, with constriction near middle, I/3 length of aedeagus.

Diagnosis. The characters of the aedeagus separate the species from all others.

Habits. The species is undoubtedly more widely distributed in Puerto Rican forests and would be frequently found by using Berlese funnels, which I did not use in Puerto Rico. It was not found in the II caves I visited.

\section{Genus Creagrophorus Matthews}

Diagnosis. Body hemispherical; darkly colored; smooth and shining. Size I.2-1.75 mm. Eyes large. Antennal grooves distinct. Antennae short; II segmented; club 5 segmented, compact, incrassate; club segments wider than long; segment eight patelliform, more short and narrow than seven and nine. Mesosternum vertical in front; without keel. Mesofemur broad, with or without hook on posterior margin. Mesotibia broad at apex, with excavation, more pronounced in male. Metafemur broad, normal in female, male with one or two hooks or teeth on posterior edge. Metatibia normal. Tarsal formula 4-4-3, or 3-3-3. Abdomen with five sternites, the first forming a long, smooth, subtriangular plate.

The genus is thoroughly described by Matthews (I888) who recognized two species from Mexico and Panama. The following is the third known species. Matthews noted the close similarity of this genus to the eyeless Scotocryptini, which are inquilines in Meliponine bee nests. Only the Scotocryptini share with Creagrophorus the unusual shape of the first abdominal sternite. Matthews described Creagrophorus with a 4-4-3 tarsal formula and noted that 

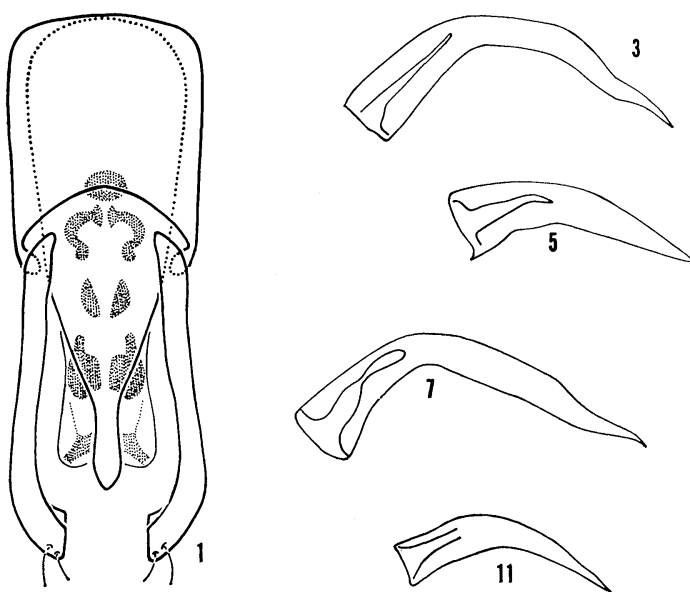

4
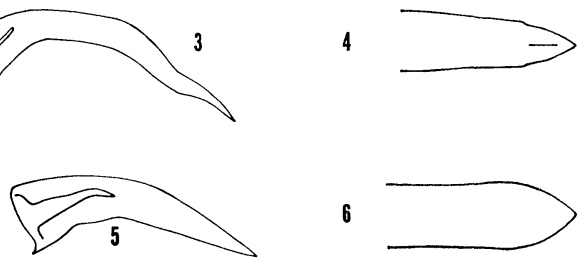

6
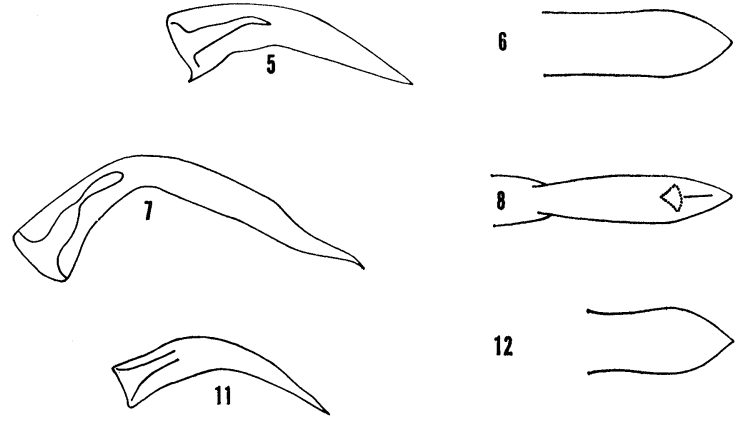

12
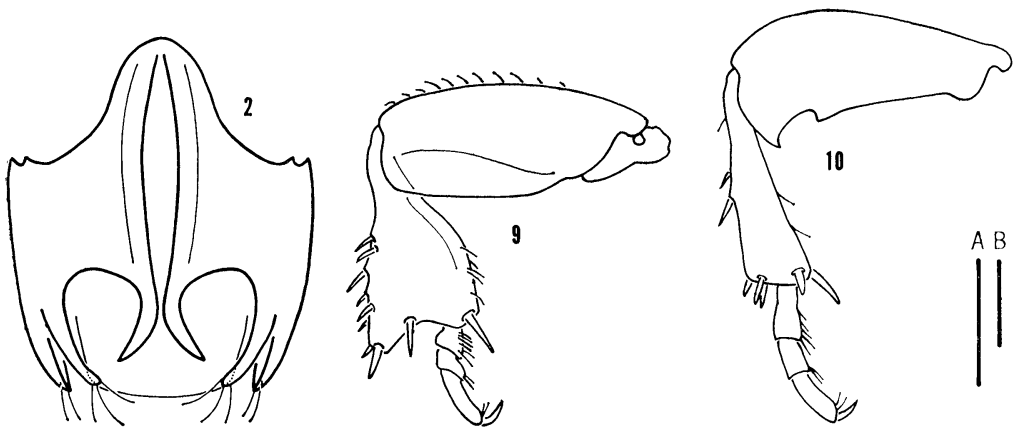

Figures 1-12. 1, dorsal aspect of aedeagus, Dissochaetus jamaicensis. 2, ventral aspect of genital segment, D. jamaicensis. 3, lateral aspect of aedeagus, Aglyptinus dimorphicus. 4, dorsal aspect of aedeagus tip, $A$. dimorphicus. 5, lateral aspect of aedeagus, $A$. jamaicensis. 6, dorsal aspect aedeagus tip, $A$. jamaicensis. 7, lateral aspect of aedeagus, $A$. puertoricensis. 8, dorsal aspect of aedeagus tip, $A$. puertoricensis. 9, ventral surface right mesothoracic leg, Creagrophorus jamaicensis. 10, ventral surface right metathoracic leg. C. jamaicensis. 11, lateral aspect aedeagus tip, $C$. jamaicensis. 12, dorsal aspect aedeagus tip, $C$. jamaicensis. Scale line A $0.25 \mathrm{~mm}$, for figs. $3-8$ and 11-12. Scale line B $0.20 \mathrm{~mm}$, for figs. 9 and 10. 
this differs from the Scotocryptini which have a 3-3-3 formula. The species described below has a 3-3-3 formula (at least in the female, the male protarsal number is not known), which reinforces the similarity of the two groups. Because of the different formula of the new species, it will not key to the correct genus in Hatch (1929).

\section{Creagrophorus jamaicensis n. sp.}

Holotype, male (in INHS). Locality and data. Janaica; St. Andrew Parish, Hermitage Dam, I750' elev., Io.v.i950, H. B. Mills. Paratypes, 6 females with same data.

Description. The holotype male is missing its head and pronotum. However, characters clearly defining the species are present on the thoracic and abdominal remnants.

Length I.2-I.4 mm, width I.O-I.I mm; male elytral length I.I $\mathrm{mm}$, width I.I mm. Color medium to dark reddish brown; antennae lighter. Surface smooth and shining. Wings normal. Male mesofemur broad, without hook; mesotibia (fig. 9) broad at apex; 3 mesotarsal segments; metafemur (fig. IO) widening toward apex, with tooth I/3 from apex, and hook at apex on posterior margin; metatibia normal; 3 metatarsal segments. Female mesofemur and mesotibia similar to male; metafemur broad but without tooth and hook. Female tarsal formula 3-3-3. Aedeagus (fig. I I) small, curved and pointed in lateral view; in dorsal view (fig. I2) tip pointed; internal sac with long thin sclerotized tube; parameres fused to median lobe.

Diagnosis. The species is geographically separated from the other two known species (hamatus Matthews of Mexico and Panama, and the bihamatus Matthews of Panama), and differs morphologically from the above in the characters of the male mesoand metafemora, and tarsal formula.

\section{Acknowledgements}

The field work was supported by Evolutionary Biology Training Grants GB 3167 and GB 7346 of the National Science Foundation, Prof. Reed C. Rollins, principal investigator, Harvard University. Mr. Alan Fiske, formerly of Harvard University, provided excellent field assistance in Jamaica in the forests and caves. Mrs. Elsie Fenn, of the Inglemount Guest House of Brownstown, aided our field work considerably by gracefully tolerating our unusual activities while we stayed with her. Milton W. Sanderson loaned material from the collections of the Illinois Natural History Survey. 


\section{Literature Cited}

HaTCH, M. W.

1929. The genera and subgenera of Leiodidae and Clambidae. Jr. New York Ent. Soc. 37: 1-6.

HLISNIKovsKY, J.

1964. Die Gattung Aglyptinus Cock. (Coleoptera, Leiodidae, Agathidiini). Reichenbachia. 2: 185-198.

JEANNEL, R.

1936. Monographie des Catopidae. Mem. Mus. Nat. Hist. Natur., Paris, nouv. ser., 1, 433 pp.

Matthews, A.

1888. Silphidae. Biologia Centrali-Americana. Coleoptera 2(1): 72101.

PECK, S.

1970. The Catopinae (Coleoptera: Leiodidae) of Puerto Rico. Psyche, 77: 237-242.

WoLcotT, G.

1936. Insectae Borinquenses, a revised annotated checklist of the insects of Puerto Rico. Jr. Agric. Univ. Puerto Rico, 20: 1-600. 

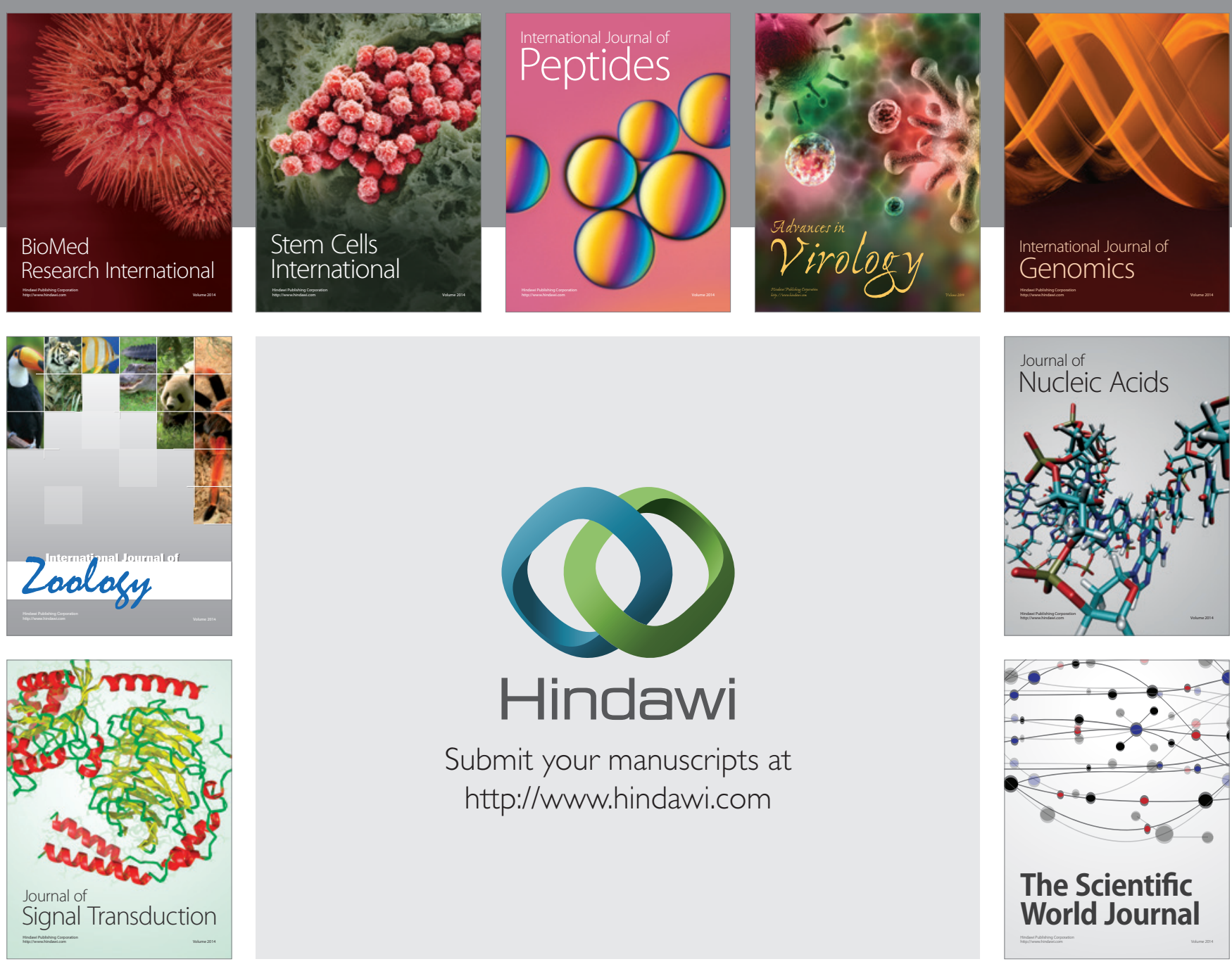

Submit your manuscripts at

http://www.hindawi.com
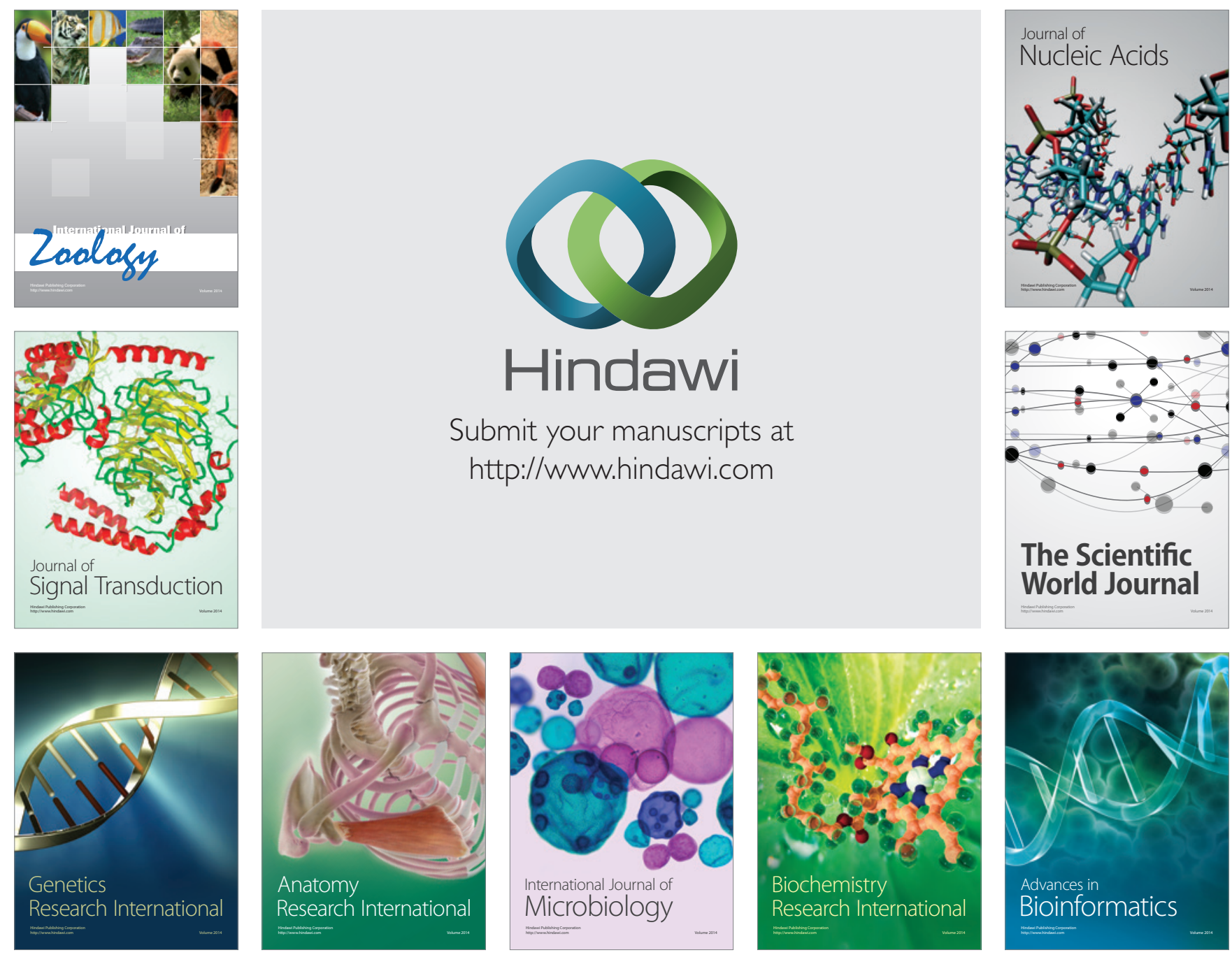

The Scientific World Journal
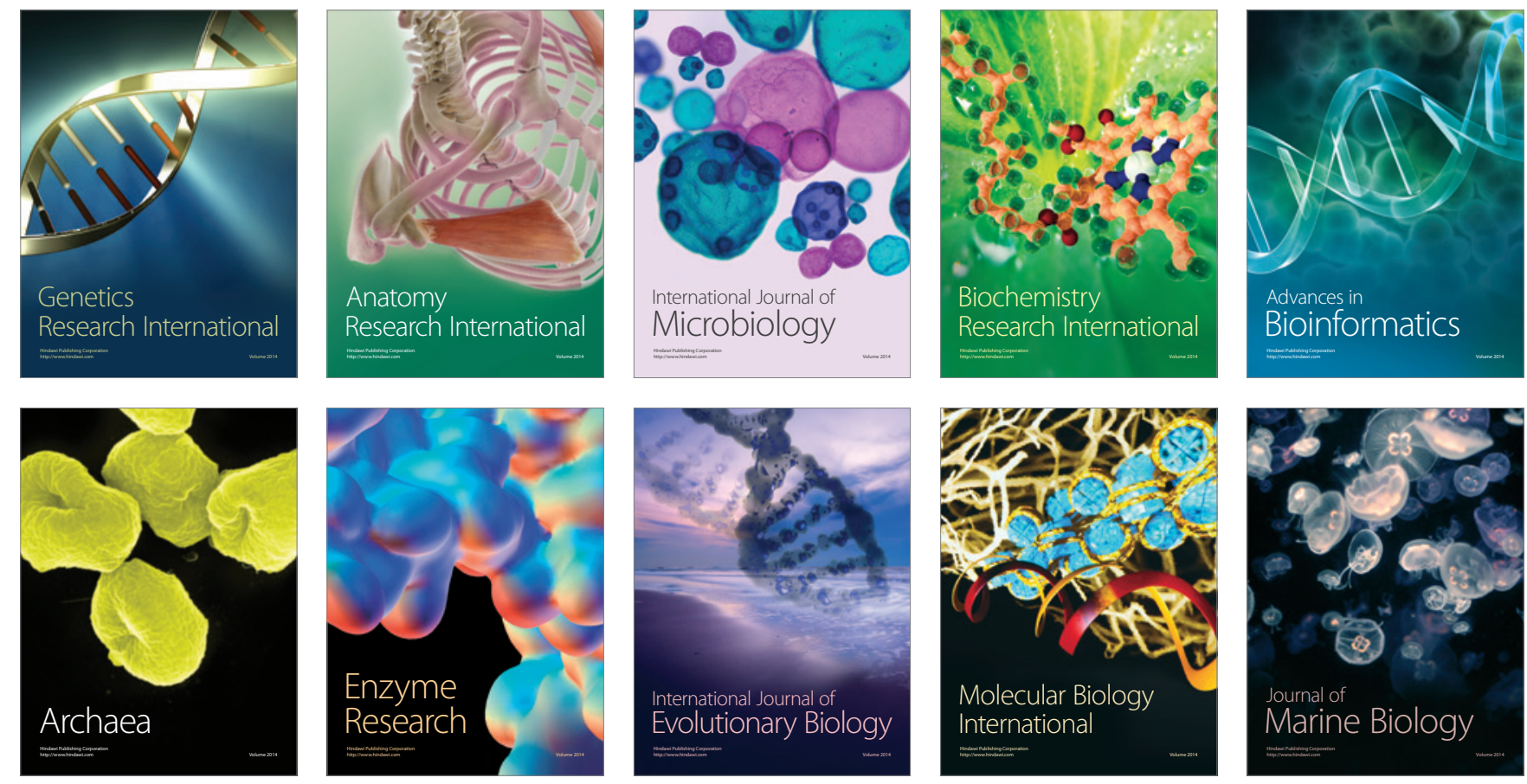